\title{
Public Trust, Taxes and the Informal Sector
}

\author{
Ceyhun Elgin* \\ Boğaziçi University
}

\author{
Mario-Solis Garcia** \\ Macalester College
}

\begin{abstract}
Several studies surprisingly associate higher taxes with smaller informal economy. To account for this phenomenon we build a simple model of optimal taxation and argue that this can be explained by differences in public trust in governments. In equilibrium, if producers' trust in the government is lower (higher), the government announces a lower (higher) tax rate on the formal sector, but more (fewer) producers chose to stay in the informal economy. Finally, using panel data estimation techniques we provide empirical support for our theory.
\end{abstract}

Keywords: informal sector, tax evasion, public trust, subgame-perfect equilibrium.

JEL Classification Numbers: H21, H26, O17.

\section{Kamu Güveni, Vergiler ve Kayıtdışı Ekonomi}

\section{Özet}

Kayıtdışı ekonomi üzerine yapılan çeşitli araştırmalar, biraz da şaşırtcı bir şekilde yüksek vergileri daha küçük bir kayıtdışı ekonomi ile ilişkilendirmektedir. Bu olguyu açıklayabilmek amaciyla, bu makalede basit bir optimal vergi modeli kuruyor ve bu gözlemin devletlere olan kamusal güvendeki farklılıklardan kaynaklanabileceğini iddia ediyoruz. Modeldeki dengede, üreticilerin devlete olan güvenleri azaldığında (arttı̆̆ında) devlet, kayıtlı ekonomi üzerinde daha düşük (yüksek) bir vergi oranı uygulamakta, ama daha çok (az) üretici kayıtdışı ekonomide kalmayı seçmektedir. Son olarak, panel veri tahminleme yöntemlerini kullanarak, kurduğumuz teori için ampirik destek de sunmaktayız.

Anahtar kelimeler: kayıtdışı ekonomi, vergi kaçırma, kamu güveni, alt-oyun mükemmel dengesi

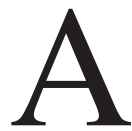

common result in models dealing with an informal sector is a positive relationship between the level of tax rates and the size of the informal sector. A non-exhaustive list of the papers in this literature includes Rauch (1991), Loayza (1996), Fortin et al. (1997), Ihrig and Moe (2004), Busato and Chiarini (2004), Amaral and Quintin (2006) and more recently Delipalla (2009). By treating taxes as exogenous and letting the informal sector not pay any taxes (or pay only a fraction

\footnotetext{
* Ceyhun Elgin is an Assistant Professor in the Department of Economics at Boğaziçi University, Natuk Birkan Building, 34342, Bebek, Istanbul, Turkey. E-mail: ceyhun.elgin@boun.edu.tr.

** Mario Solis-Garcia is an Assistant Professor in the Department of Economics at Macalester College, 1600 Grand Avenue, Carnegie Hall Room 310C Saint Paul, MN 55105. E-mail: msolisga@macalester.edu.
} 
of those paid by the formal sector), this result is immediately obvious in a two-sector (formal and informal) neoclassical growth model where the role of the government is passive.

The problem with the theoretical result described above is that it is not supported by recent comprehensive empirical studies. Even though earlier empirical studies, using either firm-level or macro data of limited size on the informal economy such as Frey and Pommerehne (1984), Schneider (1994,1997), Tanzi (1999) and Davis and Henrekson (2004) have shown that, where taxes are left to play only an exogenous role, they provide support for a positive correlation between taxes and the informal sector size; several recent cross-section and panel data empirical studies, using considerably larger datasets and allowing for the possible endogeneity of taxes, associate higher taxes with a smaller size of the informal economy. Examples are Johnson et al. (1997), Johnson et al. (1998), Friedman et al. (2000), and Torgler and Schneider (2007). ${ }^{[1]}$ Plotting informal sector size vs. tax burden, corporate tax rate, average labor income tax rate, or top marginal income tax rate in a cross-section clearly indicates a negative relationship between these variables. ${ }^{[2]}$ In particular, Figure 1 shows the relationship between the size of the informal sector and the tax burden. Moreover, the above-mentioned studies show that this negative empirical relationship remains significant even after controlling for several variables. Additionally, on the theoretical side, Aruoba (2010), Hatipoğlu and Özbek (2011), and Elgin (2011) are among the exceptions, showing that endogenizing taxes has the potential to account for the negative correlation between taxes and informality.

In this paper, in contribution to this latter stream of literature, we develop a simple model of optimal taxation and argue that the negative correlation between tax rates and the size of the informal sector can be explained by differences in public trust in governments. In our model, given a tax rate set by the government, producers choose whether to operate in the informal sector and not pay any taxes or to stay in the formal sector, thus gaining access to capital markets, but facing government scrutiny and paying taxes. Given the producers' optimal behavior, the government chooses the tax rate to maximize its expected tax revenue. The key friction we introduce in the model is that producers do not fully trust the government's policy announcement and believe that it might expropriate the formal producers' output. In equilibrium, if producers' trust in the government is lower (higher), the government announces a lower (higher) tax rate on the formal sector, but more (fewer) producers choose to stay in the informal economy. Finally, using dynamic panel estimation techniques, we present empirical evidence that our theory is consistent with the data. Specifically, we show that once certain institutional and political risk variables that we use to proxy public trust are controlled for, the data indicates a positive correlation between the tax rate and the size of the informal economy.

\footnotetext{
[1] Friedman et al. (2000) provides an excellent account of the literature on the relationship between taxes and informality.

[2] Tax burden is defined as the ratio of the total tax revenue to GDP. Sources of this data will be made clear in the empirical section of the paper.
} 
The rest of the paper is organized as follows: The next section describes the model economy. Then we present simulations of the model economy numerically characterizing the model. In this section we also compare the model against the data. In section four we conduct a panel data econometric analysis which supports the hypotheses implied by the model. Finally, we provide concluding remarks.

Figure 1

\section{Informal Sector vs. Tax Burden}

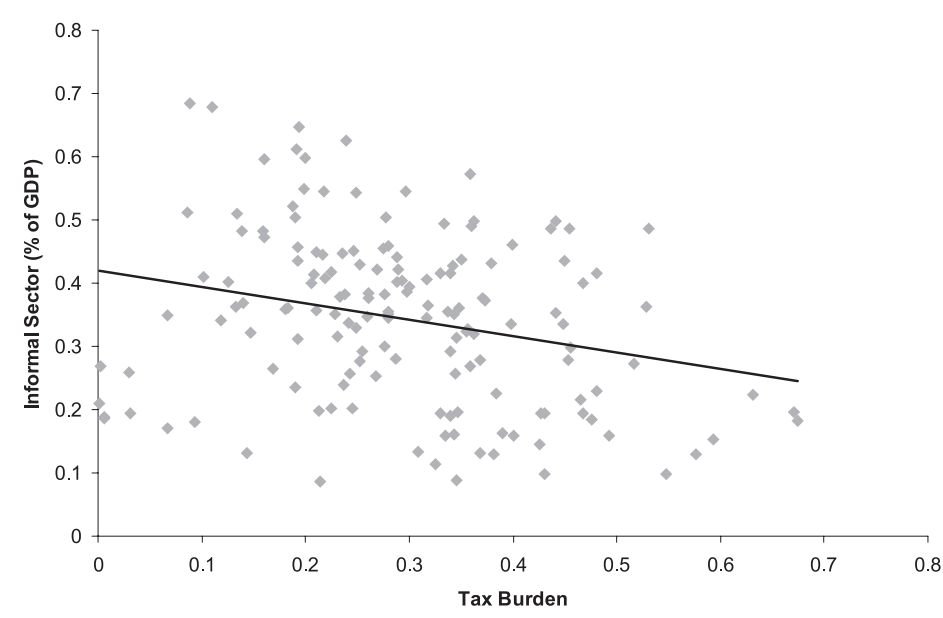

\section{A Simple Model}

We assume that there are two kinds of agents in the economy, a continuum $[0,1]$ of household-producers, each denoted by $i$, and a government. We assume householdproducers (in short, households) have access to two production technologies which allow them to produce output.

In turn, each household obtains utility from the resulting profits; this is,

$$
U(i)[\pi(i)]=\mathbb{E} u[\pi(i)]
$$

where $\mathrm{E}$ is the expected value operator, $\mathrm{U}($.$) is a strictly increasing, concave, and twice$ continuously differentiable function, and $\pi$ represents household i's profits. ${ }^{[3]}$

All households have identical preferences and are endowed with one unit of time which they can only use for labor. We also assume that each household draws a productivity parameter $\theta(i)$ from some known distribution $\theta$. Then the household decides on which technology to use, in other words choses in which sector to supply its labor input $\mathrm{N}(\mathrm{i})=1$. The production technologies, here denoted formal and informal, are explained below as follows:

${ }^{[3]}$ In what follows, we will assume linear utility for simplicity. 


\section{Formal Technology:}

The first production technology combines each household's capital K(i) ${ }^{[4]}$ and labor $\mathrm{N}(\mathrm{i})$ to produce output $\mathrm{Y}(\mathrm{i})$. We assume that this technology takes the following functional form:

$$
Y_{F}(i)=\exp [\theta(i)][K(i)]^{\alpha}[N(i)]^{1-\alpha}=\exp [\theta(i)][K(i)]^{\alpha}=z(i)[K(i)]^{\alpha}
$$

where $\theta(i)$ is household i's productivity parameter, $0<\alpha<1$, and where we define $z(i)=$ $\exp [\theta(\mathrm{i})]$. (Also, the value of $\alpha$ is the same for all households.) As mentioned above, households can provide labor but have no capital: They need credit to produce their optimal level of output. We further assume that the only way that households can access the credit market is if they decide to become part of the formal sector. It is a simple matter to verify that a formal household's expected profits are given by the following:

$$
\mathbb{E} \pi_{F}(i)=Y_{F}(i)-r K(i)-\mathbb{E} T(i)
$$

where ET(i) are the household's expected tax payments.

\section{Informal Technology}

The second production technology consists of a labor-exclusive process which provides output to obtain utility above a minimum subsistence level. We think of this as a residual technology in the sense that households that decide to go to the informal sector are obliged to use this technology (given their inability to get capital). We assume this technology takes the following functional form:

$$
Y_{I}(i)=\exp [\theta(i)]\left[N_{i}\right]=z(i)
$$

Consequently, profits for an informal household are given by

$$
\pi_{I}(i)=Y_{I}(i)
$$

In this sense, a household's decision is simple: Become a part of the formal sector or a part of the informal sector. Households that choose to go to the formal sector are required to pay a rent for the capital used (here assumed to be some exogenous value $\mathrm{r}$ dictated by an authority external to the model, like a central bank) and are required to pay taxes. On the other hand, households in the informal sector are not subject to government taxation but also do not have access to capital.

It follows that the utility maximization problem of household $i$ is given as

$$
\max _{K(i) \geq 0}\left\{\mathbb{E} u\left[\pi_{F}(i)\right], u\left[\pi_{I}(i)\right]\right\}
$$

[4] To keep the model as simple as possible we assume that households have access to as much capital as they want to employ in the production at some exogenous rate $\mathrm{r}$. 
Now we turn to the second agent of our model economy, the government.

\section{The Government}

There is a government in the model that wishes to maximize its tax revenues $\mathrm{R}$. We assume that the government announces a plan to charge formal households a percentage $\tau$ of their output. ${ }^{[5]}$

Households that decide to become a part of the formal sector have to turn in all relevant asset and output information to the government; a household loses all possibility of hiding any outcome from the government. ${ }^{[6]}$ Furthermore, we assume here that households form an expectation relative to the government's announced tax schedule. With some probability $\lambda$ they believe that the government will commit to its announcement and impose the announced rate $\tau$. However, there is the added chance, $1-\lambda$ of the risk of expropriation. ${ }^{[7]}$ For a household in the formal sector, expected tax payments ET(i) take the form of:

$$
\mathbb{E} T(i)=[\lambda \tau+(1-\lambda)] z(i)[K(i)]^{\alpha}
$$

where $\tau$ is the originally-announced taxation plan of the government.

Therefore, the government solves the following problem: ${ }^{[8]}$

$$
\max _{\tau} \int_{\theta_{V}}^{1} R f(i) d i=\max _{\tau} \int_{\theta_{V}}^{1} \tau z(i)[K(i)]^{\alpha} f(i) d i
$$

where $\theta_{V}$ is the potential threshold where households having a productivity above it choose to operate in the formal sector, thereby constituting the tax base of the government.

The timing of the static game is as follows: First, households receive their productivity parameter $\theta(\mathrm{i})$. Next, the government announces the tax rate it is supposed to charge on formal output, $\tau$. Households observe the government's decision and, contingent on their productivity parameter $\theta(\mathrm{i})$ and their beliefs about the government's commitment to $\tau, E(\lambda)$ decide to go formal or informal. Formal agents access the credit market, obtain their optimal level of K(i) and produce. The government observes all formal agents and their output; then, it taxes according to the original plan. Households get utility U(i) $[\pi(i)]$ and the government consumes the value of the tax revenue which results after solving its own maximization problem.

Given the description of the model above, we can now define the competitive equilibrium.

\footnotetext{
[5] We have also performed the same calculations for the case of a proportional tax on profits; since the qualitative and quantitative results are not changed, we use the proportional tax over output throughout the document. These alternative simulations can be obtained from the authors upon request.

[6] One can also interpret this that in exchange, the government extends a "quality seal" that allows households to access the credit market.

[7] Here, we interpret $\lambda$ to some extent as a proxy variable for public trust depending on institutional quality and government commitment.

${ }^{[8]}$ Our results are not sensitive to whether the government also forms an expectation over the two possible outcomes or not.
} 
Definition 1: A competitive equilibrium of the above defined environment is given by the tax rate $\tau, \mathrm{K}(\mathrm{i}), Y_{I}(\mathrm{i})$ and $Y_{F}(\mathrm{i})$ for all $\mathrm{i}$ in $[0,1]$ such that given $\tau, \mathrm{r}$, and $\lambda ; \mathrm{K}(\mathrm{i})$, $Y_{I}(\mathrm{i})$ and $Y_{F}(\mathrm{i})$ solve the household producers' problem defined above for all i.

In the competitive equilibrium, only households above some threshold level of productivity choose to stay in the formal sector. This result is stated in the proposition below:

Proposition 1: Taking $\lambda$ as given, a household $i$ with a productivity parameter $\theta(i)$ operates in the formal sector if and only if $\theta(\mathrm{i})>\theta_{v}(\mathrm{i})$, where $\theta_{v}(\mathrm{i})$ is defined by

$\theta_{V}(i)=\left(\frac{\alpha-1}{\alpha}\right)\left[\log (1-\tau)+\log A+\log \lambda-\left(\frac{\alpha}{1-\alpha}\right) \log r\right]$

where

$A:=\left(\alpha^{\alpha / 1-\alpha}-\alpha^{1 / 1-\alpha}\right)$

Proof:

Consider any household $i$ with productivity parameter $\theta(i)$. If the household decides to go to the formal sector, its profits are given by the formal sector profits defined above. In that case the first-order condition with respect to capital implies that the optimal level of capital should satisfy

$$
K(i)=\left[\frac{\alpha \lambda(1-\tau) z(i)}{r}\right]^{\frac{1}{1-\alpha}}
$$

Using the above equation, and recalling the household's problem, it follows that a household shows no preference between operating in the formal or the informal sector if and only if its profits are the same in either sector; that is, if and only if $\pi_{F}(i)=\pi_{I}(i)$ or

$$
A\left[\frac{\lambda(1-\tau) z(i)}{r^{\alpha}}\right]^{\frac{1}{1-\alpha}}=z(i)
$$

Apply the $\log$ function to the equation above and rearrange to get the desired result $\theta_{v}$.

Notice that, since we assume the existence of a unit measure of households, we can interpret $\theta_{v}(\mathrm{i})$ as a proxy for the size of the informal sector. ${ }^{[9]}$

Moreover, a straightforward application of Proposition 1 is presented in Corollary 1.

Corollary 1: If the government decides to reduce taxes $\tau$, or if the exogenous authority (for example the central bank) decides to decrease the interest rate $r$, or if there is an increase in the public trust in the government, the size of the formal sector increases.

[9] Notice that the actual size of the informal sector as a percentage of formal output is given by the following expression which obviously is an increasing function of $\theta \mathrm{v}(\mathrm{i}): \frac{\int_{0}^{\theta_{V}(i)} Y_{I}(i) f(i) d i}{\int_{\theta_{V}(i)}^{1} Y_{F}(i) f(i) d i}$ 
Proof:

It is straightforward to verify that

$\frac{\partial \mathbb{E} \pi_{F}(i)}{\partial \tau}=-\Gamma\left[\frac{\lambda z(i)}{r^{\alpha}}\right]<0, \quad \frac{\partial \mathbb{E} \pi_{F}(i)}{\partial r}=-\alpha \Gamma\left(\frac{1}{r^{\alpha+1}}\right)<0$

And

$\frac{\partial \mathbb{E} \pi_{F}(i)}{\partial \lambda}=\Gamma\left[\frac{(1-\tau) z(i)}{r^{\alpha}}\right]>0$

where

$$
\Gamma=\left(\frac{A}{1-\alpha}\right)\left[\frac{\lambda(1-\tau) z(i)}{r^{\alpha}}\right]^{\frac{\alpha}{1-\alpha}}
$$

Here we should note that, taking taxes exogenously given, we still have a positive correlation between the level of taxes and the size of the informal sector. Keeping the discussion we made in the introduction in mind, this is not surprising. Our next task is to endogenize the determination of taxes.

\section{Subgame-perfect Equilibrium}

Remark 1: Using the backward solution algorithm, given the announced $\tau$ and $\lambda$, the value of $\theta_{v}(\mathrm{i})$ can be obtained from Proposition 1 . The government can also calculate this cutoff value (which depends on $\tau$ ) and then can choose $\tau$ to solve

$$
\max _{\tau \in[0,1]} \quad \int_{\theta_{V}(\tau)}^{1} A[1-(1-\tau)]\left[\frac{z(i)}{r^{\alpha}}\right]^{\frac{1}{1-\alpha}} f(i) d i
$$

Definition 2: A subgame-perfect equilibrium of the above-defined environment is given by the tax rate $\tau, \mathrm{K}(\mathrm{i}), Y_{I}(\mathrm{i})$ and $Y_{F}(\mathrm{i})$ for $\mathrm{i}$ in $[0,1]$ such that given $\mathrm{r}$, and $\lambda$;

- The tax rate $\tau$ solves the government's problem.

- For every possible $\tau$ in $[0,1] ; \tau, \mathrm{K}(\mathrm{i}), Y_{I}(\mathrm{i})$ and $Y_{F}(\mathrm{i})$ constitute a competitive equilibrium.

In noticing that the informal sector size, $\theta_{v}(i)$ and the tax rate, $\tau$, are both endogenously determined in the model, we specifically want to obtain comparative static results with respect to $\lambda$. Unfortunately, the above-defined government maximization problem does not allow us to obtain analytical results. However, it is straightforward to numerically simulate the model economy and characterize it through numerical simulations. 


\section{Numerical Results}

We perform a set of numerical simulations ${ }^{[10]}$ to get a flavor of the implications of Proposition 1 and Corollary 1.

\section{Cutoff Productivity and Tax Revenue with Variable Taxes}

We are first interested in determining how the cutoff productivity value and the government's tax revenue $R$ are affected by varying the value of taxes $\tau$, for a given value of $\lambda$. To do this, we create a grid (of step size 0.01 ) and we allow $\tau$ to move in the interval $[0.01,0.99]$, fixing the value of $\lambda^{[11]}$ at 0.75 . We perform 1,000 repetitions and obtain the average values for $\theta_{v}$ and R. Figure 2 below shows the results of this simulation.

Figure 2

\section{Tax Revenue and Cutoff Productivity with Varying Taxes}

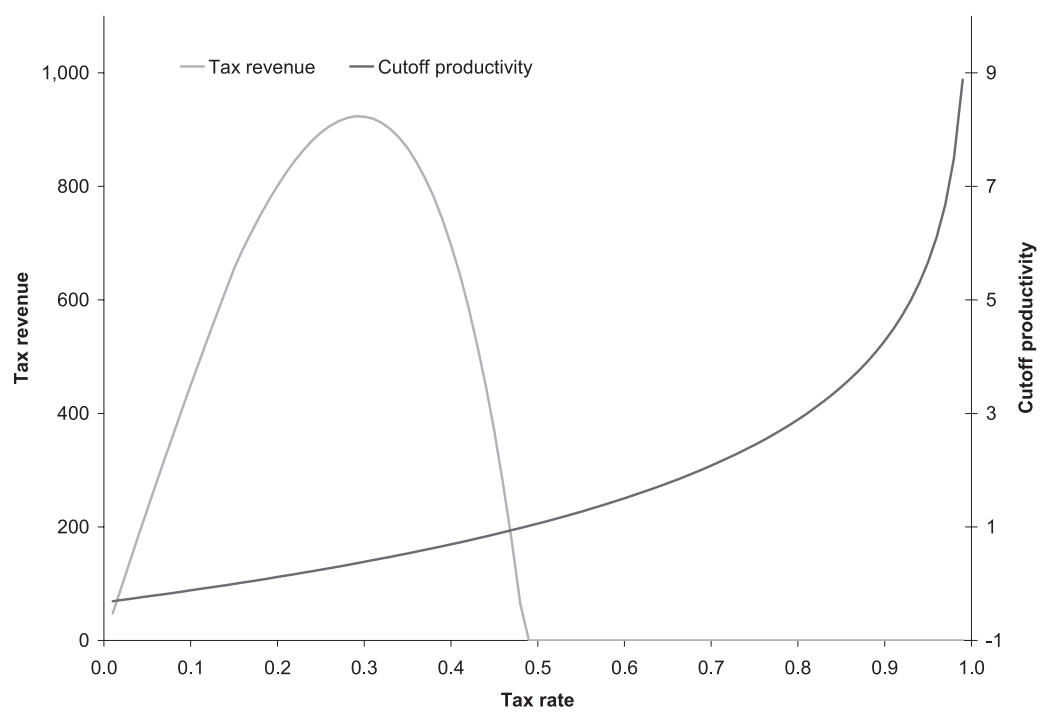

From Figure 2 we observe that, keeping the level of public trust constant, tax receipts show a Laffer effect and the total revenue of the government is maximized when $\tau=$ 0.29. (For our simulation, $\mathrm{R}=0$ for $\tau>0.49$ because all households become informal after this level of $\tau$.) In addition, and as claimed above, the higher the tax rate, the higher the cutoff productivity value (i.e., the value of $\theta_{v}$ ) needs to be in order to remain in the formal sector.

\footnotetext{
${ }^{[10]}$ In all of the simulations, unless otherwise noted, we choose parameter values $\alpha=1 / 3$ and $\rho=0.06$, and we also assume $\theta(i)$ comes from a standard normal distribution. We allow for a population of 1,000 households. Our results are qualititatively robust with respect to the changes in the number of households or the choice of the parameters.

${ }^{[11]}$ Setting $\lambda$ equal to 0.75 is only for expositional purposes and does not qualititatively change the results.
} 


\section{Cutoff Productivity and Tax Revenue with Variable Commitment}

Our second experiment is to determine how $\theta_{v}$ and $\mathrm{R}$ are affected by varying the value of $\lambda$ for a given tax rate. We follow the procedure of the last subsection, and we allow $\lambda$ to move in the interval [0.01,0.99], fixing the value of $\tau$ at 0.25 . Again, we perform 1,000 repetitions and obtain the average values for $\theta_{v}$ and R. Figure 3 below shows the results.

Figure 3

\section{Tax Revenue and Cutoff Productivity with Varying Public Trust}

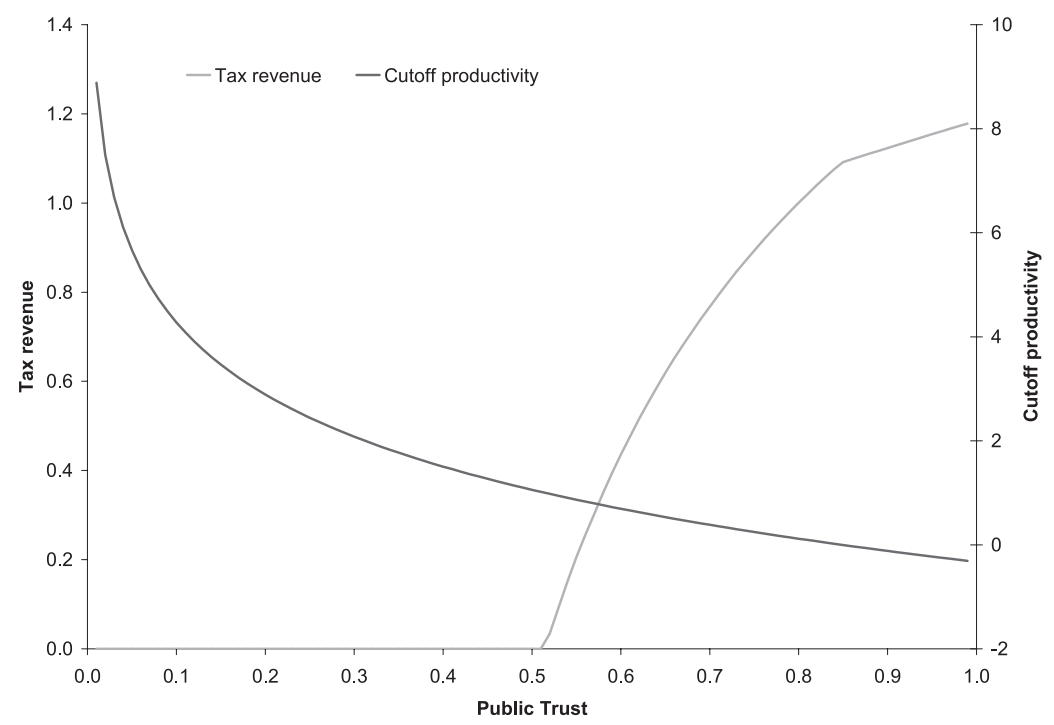

From Figure 3 we observe that the cutoff productivity value decreases as $\lambda$ increases. Moreover, tax revenue is positive and strictly increasing in $\lambda$ provided that $\lambda>0.5$.

\section{Cutoff Productivity and Tax Revenue: the General Case}

Finally, now we allow for both $\lambda$ and $\tau$ to vary simultaneously to get a flavor of the characterization of the subgame-perfect equilibrium. To keep the results manageable, we perform a simulation where we use a grid of step size 0.1 , and we move $\lambda$ between 0.1 and 1.0 , and $\tau$ between 0.1 and $0.9 .{ }^{[12]}$ As was the case in the previous subsections, we perform 1,000 repetitions and obtain the average values for $\theta_{v}$ and $\mathrm{R}$.

In order to fully characterize a result that is dependent both on the productivity parameter $\theta_{v}$ and on the tax announcement $\tau$, we use the following simplification: The values

\footnotetext{
${ }^{[12]}$ We make the decision to truncate the value of $\tau$ at 0.9 for two reasons. First, as suggested by Figure 3 , values of $\tau$ greater than a threshold are not relevant in terms of revenue maximization for the government. Second, as $\tau$ approaches 1 , the cutoff productivity value increases exponentially; this complicates the interpretation of the results.
} 
of the $\mathrm{x}$-axis take the form $\mathrm{x}=10 \lambda+\tau$; in this way, a value of $\mathrm{x}$ of 4.6 has associated parameters of $\lambda=0.4$ and $\tau=0.6$. Figure 4 below shows the results of this procedure:

Figure 4

Tax Revenue and Cutoff Productivity with Varying Taxes and Public Trust

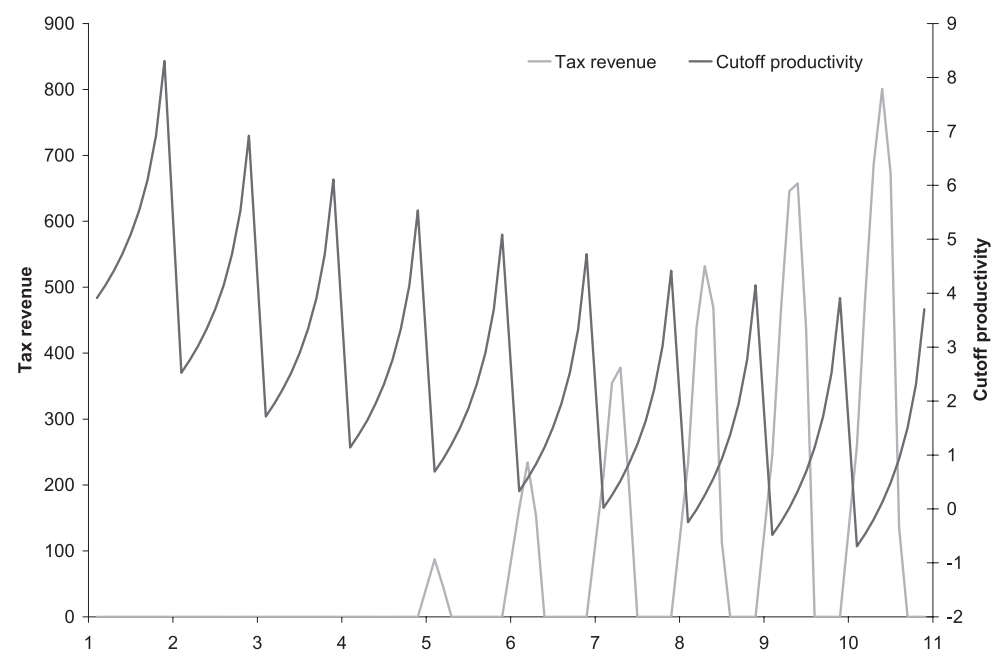

On the other hand, in Figure 5, we change $r$ to 0.02. From the figures it is clear that cutoff productivity for being formal has a positive relationship with $\tau$ and a negative relationship with $\lambda$.

Figure 5

Tax Revenue and Cutoff Productivity with Varying Taxes and Public Trust (r=0.02)

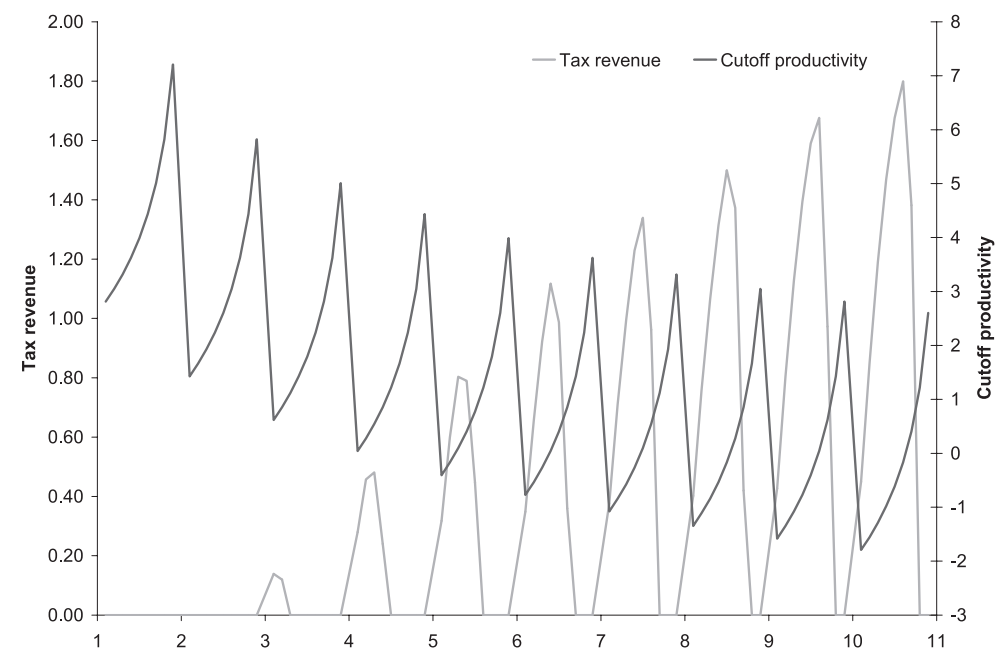




\section{Endogeneous Taxes}

Now we look at the numerical characterization of the subgame-perfect equilibrium where the government chooses the optimal tax rate on the formal sector to maximize its revenue. Our ultimate purpose here is to get comparative static results of all the relevant variables including $\tau$, with respect to $\lambda$. For this subsection we use $\alpha=0.4$ and $\mathrm{r}=0.07^{[13]}$ We again assume that the productivity parameter is coming from a standard normal distribution and allow for a population of 1,000 households.

Figure 6 presents the behavior of the optimal tax rate $\tau$ obtained from the government's problem with respect to $\lambda$. The main result is that higher public trust allows for a government to charge a higher tax rate on the formal sector.

Figure 6

\section{Optimal Tax Rate and Public Trust}

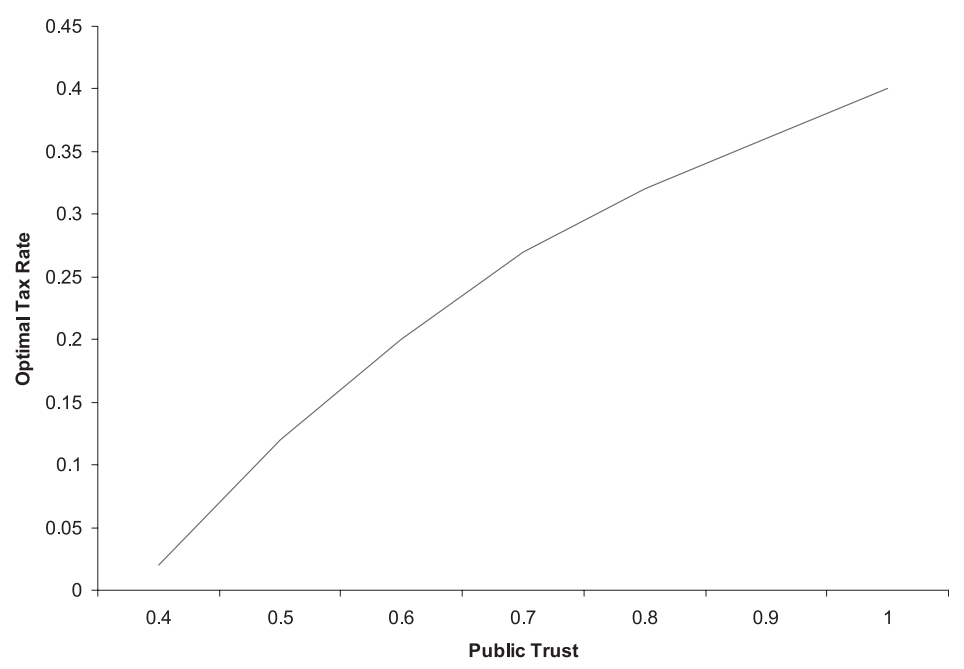

On the other hand, Figure 7 shows that the informal sector size is a decreasing function of $\lambda$. Notice that Figure 3 draws a similar relationship. However, as opposed to Figure 3 , in Figure 7 with increasing $\lambda$, not only does informal sector size decrease but also we have an increasing level of $\tau$. In other words, increasing public trust increases the tax rate but reduces the informal sector size at the same time.

Finally, in Figure 8 we compare the model simulation against its data counterpart. Specifically, for different degrees of $\lambda$, we regress the model-generated informal sector size on the optimal tax rate given by the model. This is the line denoted by "model." To compare it against the data, Figure 8 also plots informal sector size in the data against the tax burden, along with the simple linear regression line obtained using these vari-

[13] The parameter values we used in the previous subsections were chosen somewhat arbitrarily. However, one ultimate purpose of this subsection is to compare the model simulations against the data. Therefore, as the next section will document, the average risk premium in the data is 0.07 . Moreover, we chose $\alpha$ to bring the model as close as possible to the data. 
ables in the data. Our choice of $\alpha=0.4$ now becomes clear as we have chosen its value to make the model generated regression line as close as possible to its data counterpart. In summary, we can say that the model is successful in accounting for the negative cross-country correlation between taxes and the size of the informal economy.

Figure 7

\section{Cutoff Productivity vs. Public Trust}

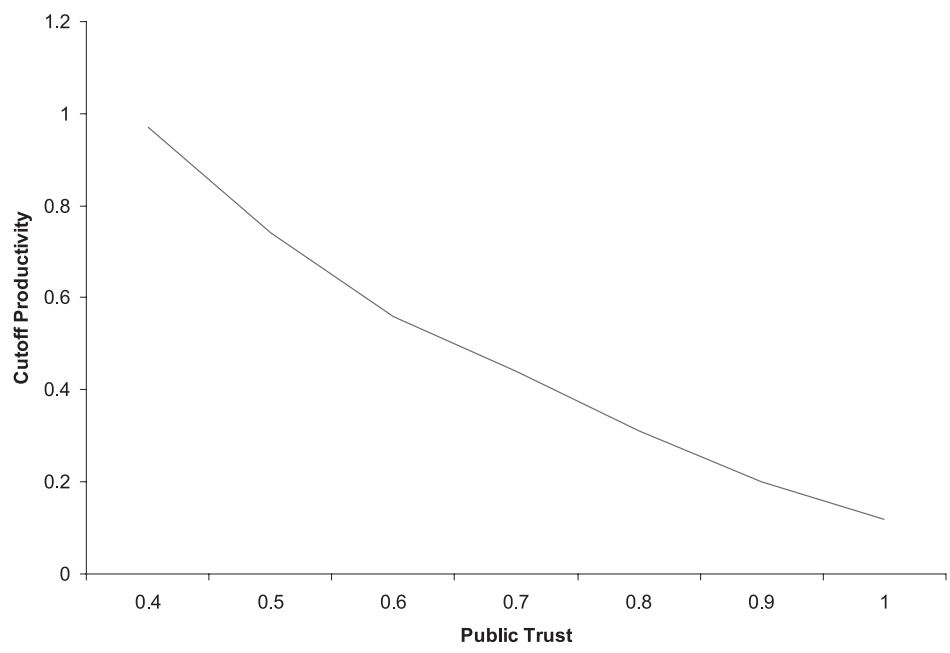

Figure 8

Data vs. Model Regressions

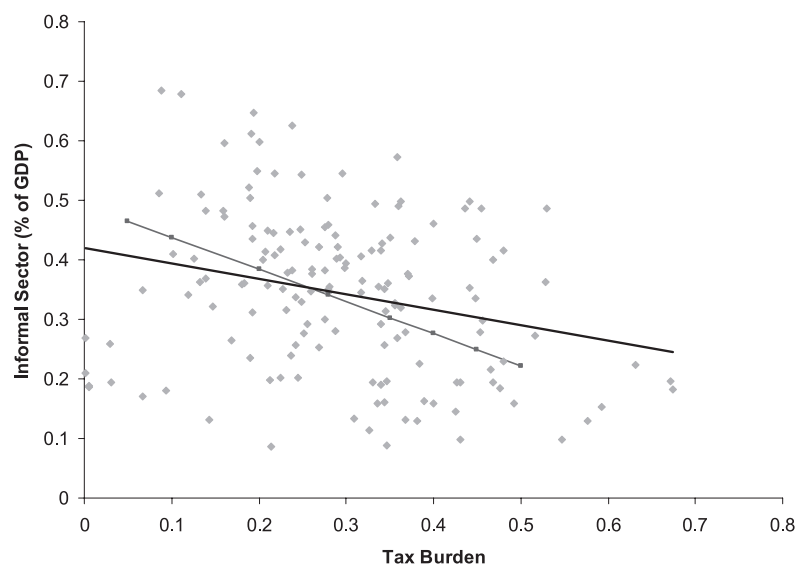




\section{Empirical Evidence}

\section{Data}

Different methodologies have been proposed in the literature to estimate the size of the informal economy for a given economy. Even though these estimations are imperfect by their nature, ${ }^{[14]}$ they are safely used for empirical cross-country analysis. In the empirical analysis, we obtain our informal sector size estimates from the widely used estimates of Schneider et al. (2010).

As a measure for taxes, in the reported results we use the tax burden data, defined as the ratio of the tax revenue to GDP, taken from the Government Finance Statistics. ${ }^{[15]}$

In the regression analysis we use several variables to $\operatorname{proxy} \lambda$ in the model. These are the government stability, rule of law, internal conflict, investment profile and democratic accountability indices obtained from Political Risk Services (ICRG) ${ }^{[16]}$ Moreover, we also use two other control variables such as GDP per-capita and risk spread. We got the data for GDP per-capita from the Groningen Economic Growth and Development Center and the risk premium both from Moody's and Aswath Damodaran's website at: http://pages.stern.nyu.edu/ adamodar/.

Table 1

\section{The Results of the Simulation}

\begin{tabular}{l|l|l|l|l}
\hline & Mean & Std. Dev. & Minimum & Maximum \\
\hline Tax Burden (in \%) & 29.30 & 13.43 & 0.10 & 67.48 \\
\hline Informal Sector Size (in \%) & 34.40 & 13.46 & 8.60 & 68.35 \\
\hline Political Stability & 9.17 & 0.99 & 6.82 & 11.36 \\
\hline Rule of Law & 3.86 & 1.30 & 1.00 & 6.00 \\
\hline Investment Role & 8.69 & 2.01 & 2.62 & 11.72 \\
\hline Democratic Accountability & 4.02 & 1.59 & 0.15 & 6 \\
\hline Internal Confict & 9.77 & 1.48 & 4.54 & 11.99 \\
\hline Risk Premium & 0.07 & 0.08 & 0.04 & 0.5 \\
\hline GDP per-capita (in thousand GK\$) & 13.37 & 9.63 & 1.20 & 36.20 \\
\hline
\end{tabular}

These are cross-section summary statistics of the panel averages.

\footnotetext{
[14] We refer the readers to Schneider (2007) for a discussion of various methods used to estimate the size of the informal sector.

[15] Several other tax indicators, tax rate on income, profits and capital gains from the World Development Indicators or the fiscal freedom index from the Heritage Foundation have also been examined and the results do not depend on the choice of the tax measure or whether we use tax burden or official tax rates for our analysis. Regression results using statutory taxes rather than tax burdens are available upon request. Moreover, also see Elgin (2010) for a discussion of the choice of the relevant tax indicator in this context.

${ }^{[16]}$ In the regressions we included these variables in one composite index named public trust defined as the sum the five variables divided by the sum of the maximum values these variables might take. This ensures that the index we have is between 0 and 1 , as with $\lambda$ we used in the model as its counterpart.
} 
Summary statistics of all variables are provided in Table 1. In total, our data is an unbalanced panel with 132 countries and a time horizon of 9 years, from 1999 to 2007.

\section{Estimation and Results}

The dynamic panel equation we estimate will be of the following form:

$$
I S_{i, t}=\beta_{0}+\beta_{1} I S_{i, t-1}+\beta_{2} \operatorname{tax}_{i, t}+\beta_{3} \operatorname{trust}_{i, t}+\sum_{k=3}^{n} \beta_{k} X_{k_{i, t}}+\theta_{i}+\gamma_{t}+\epsilon_{i, t}
$$

$\mathrm{X}$ 's are the other explanatory variables in addition to lagged informal sector size, tax burden and public trust. $\Theta$ for every country i and $\gamma$ for every year t are the country and period fixed effects, respectively. Moreover the dependent variable, IS, is the size of the informal sector relative to GDP, and tax denotes the tax burden.

Table 2

\section{Informal Sector and Tax Burden}

Dependent variable: IS

\begin{tabular}{|c|c|c|c|c|c|c|}
\hline & FE & FE & FE & GMM & GMM & GMM \\
\hline IS $(-1)$ & & & & $\begin{array}{l}0.82^{* * * *} \\
(0.12)\end{array}$ & $\begin{array}{l}0.59 * * * \\
(0.16)\end{array}$ & $\begin{array}{l}0.62^{* * *} \\
(0.15)\end{array}$ \\
\hline Tax & $\begin{array}{l}-0.02 * * \\
(0.01)\end{array}$ & $\begin{array}{l}0.02 * * * \\
(0.005)\end{array}$ & $\begin{array}{l}0.01 * * * \\
(0.005)\end{array}$ & $\begin{array}{l}-0.01 * * \\
(0.005)\end{array}$ & $\begin{array}{l}0.02 * * * \\
(0.006)\end{array}$ & $\begin{array}{l}0.002^{* * * *} \\
(0.006)\end{array}$ \\
\hline Public Trust & & $\begin{array}{l}-0.006^{* * *} \\
(0.003)\end{array}$ & $\begin{array}{l}-0.006^{* *} \\
(0.003)\end{array}$ & & $\begin{array}{l}-0.009 * * \\
(0.004)\end{array}$ & $\begin{array}{l}-0.002^{* *} \\
(0.001)\end{array}$ \\
\hline Risk Premium (r) & & & $\begin{array}{l}0.009 * * \\
(0.004)\end{array}$ & & & $\begin{array}{l}0.007 * \\
(0.004)\end{array}$ \\
\hline GDP per-capita & & & $\begin{array}{l}-0.01 * * \\
(0.005)\end{array}$ & & & $\begin{array}{l}-0.005^{* * *} \\
(0.002)\end{array}$ \\
\hline$R$-squared & 0.09 & 0.99 & 0.99 & 0.99 & 0.99 & 0.99 \\
\hline Observations & 883 & 767 & 766 & 883 & 767 & 766 \\
\hline Hansen J-Test & & & & 0.001 & 0.001 & 0.001 \\
\hline
\end{tabular}

All panel regressions include year and country fixed effects. Robust standard errors are reported in parentheses. All variables except the informal sector size are in natural logarithms. ***, **, * denote 1, 5, and 10\% confidence levels, respectively.

Basically, we run two sets of regressions. In the three columns of Table 2 (denoted by FE), we report the results of the fixed-effect linear panel regressions with AR (1) disturbances. ${ }^{[17]}$ In the last three columns (denoted by GMM) we repeat the same analysis using the generalized method of moments estimator (GMM) à la Arellano and

[17] The Hausman test points us in favor of a fixed-effect regression and the Wooldridge test rejects absence of autocorrelation. 
Bond (1991). Here we also use one-period lagged value of the independent variables as a dependent variable.

As one can observe from Table 2, if the public trust variable is not added to the regression, the coefficient of the tax rate is negative. However, once the public trust index is controlled for, the coefficient of the tax rate changes its sign and becomes positive. Even after GDP per-capita and risk premium are added to the regression analysis, the sign of the tax coefficient remains positive. This result is in line with our model where for fixed values of $\lambda$, higher taxes imply a larger informal sector.

Table 3

Systems Estimations

\begin{tabular}{|c|c|c|c|c|c|c|}
\hline & \multicolumn{2}{|c|}{ 3SLS } & \multicolumn{2}{|c|}{ OLS } & \multicolumn{2}{|c|}{ GMM } \\
\hline $\begin{array}{l}\text { Dependent } \\
\text { Variable }\end{array}$ & IS & Tax & IS & Tax & IS & Tax \\
\hline IS(-1) & $\begin{array}{l}0.51 * * * \\
(0.20)\end{array}$ & & $\begin{array}{l}0.60 * * * \\
(0.15)\end{array}$ & & $\begin{array}{l}0.62^{* * * *} \\
(0.15)\end{array}$ & \\
\hline Tax Burden & $\begin{array}{l}0.02 * * \\
(0.01)\end{array}$ & & $\begin{array}{l}0.01 * * * \\
(0.005)\end{array}$ & & $\begin{array}{l}0.02 * * \\
(0.01)\end{array}$ & \\
\hline Public Trust & $\begin{array}{l}-0.004 * * \\
(0.002)\end{array}$ & $\begin{array}{l}0.68 * * * \\
(0.20)\end{array}$ & $\begin{array}{l}-0.006^{* * * *} \\
(0.003)\end{array}$ & $\begin{array}{l}0.67 * * * \\
(0.002)\end{array}$ & $\begin{array}{l}-0.004 * * \\
(0.001)\end{array}$ & $\begin{array}{l}0.66 * * * \\
(0.19)\end{array}$ \\
\hline Risk Premium (r) & $\begin{array}{l}0.008 * * \\
(0.004)\end{array}$ & & $\begin{array}{l}0.009 * * \\
(0.004)\end{array}$ & & $\begin{array}{l}0.007 * \\
(0.004)\end{array}$ & \\
\hline GDP per-capita & $\begin{array}{l}-0.007 * * \\
(0.003)\end{array}$ & & $\begin{array}{l}-0.01 * * \\
(0.005)\end{array}$ & & $\begin{array}{l}-0.009 * * \\
(0.004)\end{array}$ & \\
\hline$R$-squared & 0.99 & 0.08 & 0.99 & 0.08 & 0.99 & 0.08 \\
\hline Observations & 766 & 766 & 766 & 766 & 766 & 766 \\
\hline
\end{tabular}

All variables except the informal sector size are in natural logarithms. All panel regressions include year and country fixed effects. Robust standard errors are reported in parentheses. ***, **, * denote 1, 5, and 10\% confidence levels, respectively.

Finally, it will also be of interest to estimate simultaneous systems of equations, as this allows us to evaluate the effect of the public trust on taxes jointly with the effects of public trust, taxes, and the effect on the informal sector size of other relevant variables. We conduct a systems estimation using three different estimators: threestage least squares (3SLSL), ordinary least-squares (OLS), and finally GMM. As the estimation results in Table 3 confirm, the empirical analysis supports our theory. Specifically, a higher level of public trust is associated with higher taxes. And once public trust is controlled for, higher taxes are associated with a larger informal sector. Moreover, higher public trust, lower risk premium and a higher level of national income are all associated with a smaller informal economy. 


\section{Concluding Remarks and Discussion}

In this paper we have developed a model to account for the surprising negative relationship between the tax burden and the size of the informal economy. Specifically, using a simple model of optimal taxation we endogenize the determination of taxes and introduce a friction into the model by allowing producers not fully to trust that the government will actually impose the announced tax rate. In equilibrium, if producers' trust in the government is lower (higher), the government announces a lower (higher) tax rate on the formal sector; but more (fewer) producers choose to stay in the informal economy. The idea here is that, once tax authorities internalize the response of agents when setting tax policy, governments that lack credibility may face very steeply decreasing returns to raising taxes and consequently may opt for lower tax rates. Since governments with less credibility are more likely to mistreat formal producers ex post facto, those economies will also tend to have smaller formal sectors. Finally, using dynamic panel estimation techniques we present empirical evidence that our theory is consistent with the data.

Our model can be extended by endogenizing the varying degree of commitment retained by governments. This can be done in a political economy model of optimal taxation.

\section{References}

Amaral, P. and Quintin, E. (2006). “A Competitive Model of the Informal Sector," Journal of Monetary Economics, 53(7): 1541-1553.

Arellano, M. and Bond, S. (1991). "Some Test of Specification for Panel Data: Monte Carlo Evidence and Application to Employment Equations," Review of Economic Studies, 58: 277-297.

Aruoba, S.B. (2010). "Informal Sector, Government Policy and Institutions," University of Maryland Working Paper.

Busato, F. and Chiarini, B. (2004). "Market and Underground Activities in a Two-Sector Dynamic Equilibrium Model,” Economic Theory, 23: 831-861.

Cowell, F.A. (1985). "The Economic Analysis of Tax Evasion," Bulletin of Economic Research, 37(3)163-193.

Davis, S.J. and Henrekson, M. (2004). "Tax Effects on Work Activity, Industry Mix and Shadow Economy Size: Evidence from Rich-Country Comparisons,” NBER Working Papers, No. 10509.

Delipalla, S. (2009). "Commodity Tax Structure and Informal Activity," Bulletin of Economic Research, 61(3)283-294.

Elgin, C. (2010). "Political Turnover, Taxes, and the Shadow Economy," Boğaziçi University, Department of Economics Working Papers, No. 2010/08.

Fortin, B., Marceau, N., and Savard, L. (1997). "Taxation, Wage Controls and the Informal Sector," Journal of Public Economics, 66: 239-312.

Frey, B.S. and Pommerehne, W.W. (1984). "The Hidden Economy: State and Prospect for Measurement," Review of Income and Wealth, 30: 1-23.

Friedman, E., Johnson, S., Kaufman, D., and Zoldo-Lobaton, P. (2000). "Dodging the Grabbing Hand: The Determinants of Unofficial Activity in 69 Countries," Journal of Public Economics, 76(3): 459-493. 
Hall, R.E. and Jones, C.I. (1999). "Why Do Some Countries Produce So Much More Output Per Worker Than Others?" Quarterly Journal of Economics, 114: 83-116.

Hatipoğlu, O. and Özbek, G. (2011). "On the Political Economy of the Informal Sector and Income Redistribution," European Journal of Law and Economics, 32 (1), 69-87.

Ihrig, J. and Moe, K.S. (2004). "Lurking in the Shadows: The Informal Sector and Government Policy," Journal of Development Economics, 73(2): 541-557.

Johnson, S., Kaufman, D., and Shleifer, A. (1997). “The Unofficial Economy in Transition,” Brookings Papers on Economic Activity, 159-221.

Johnson, S., Kaufman, D. and Zoido-Lobaton, P. (1998). "Regulatory Discretion and the Unofficial Economy," American Economic Review, 88: 387-392.

LaPorta, R., Lopez-de-Silanes, F., Shleifer, A., and Vishny, R. (1999). "The Quality of Government," Journal of Law, Economics and Organization, 15: 222-279.

Lederman, D., Loayza, N., and Soares, R.R. (2005). “Accountability and Corruption: Political Institutions Matter," Economics and Politics, 17(3): 1-35.

Loayza, N.V. (1996). "The Economics of the Informal Sector: A Simple Model and Some Empirical Evidence from Latin America," Carnegie-Rochester Conference Series on Public Policy, 45: 129-162.

Rauch, J.E. (1991). "Modeling the Informal Sector Formally," Journal of Development Economics, 35: 33-48.

Schneider, F. (1994). "Measuring the Size and Development of the Shadow Economy: Can the Causes Be Found and the Obstacles Be Overcome?," in H. Brandstaetter and W. Goth, (eds.), Essays on Economic Psychology: 193-212. Berlin: Springer.

-----, (1997). “The Shadow Economies of Western Europe,"Economic Affairs, 17(3): 42-48.

-----, (2007). "Shadow Economies and Corruption All Over the World: New Estimates for 145 Countries," Economics: The Open-Access, Open-Assessment E-Journal, 1(9): 1-66.

Schneider, F., Buehn, A., and Montenegro, C.E. (2010). "Shadow Economies all over the World: New Estimates for 162 Countries from 1999 to 2007," World Bank Policy Research Working Paper Series, 5356.

Tanzi, V. (1999). "Uses and Abuses of Estimates of the Underground Economy," Economic Journal, 109: F338-F347.

Torgler, B. and Schneider, F. (2007). "Shadow Economy, Tax Morale, Governance and Institutional Quality: A Panel Analysis," IZA Discussion Papers, 2563. 